\title{
ひも状ミセル水溶液中を伝播するせん断波の可視化による粘弾性計測
}

\author{
山本 将寛 ${ }^{* 1}$ ，三神 史彦 ${ }^{* 2}$
}

\section{A viscoelastic measurement with visualization of shear waves in a wormlike micellar fluid}

\author{
Masahiro YAMAMOTO*1 and Fumihiko MIKAMI ${ }^{* 2}$ \\ ${ }^{* 1 * 2}$ Department of Mechanical Engineering, Chiba University, \\ 1-33 Yayoi-cho, Inage-ku, Chiba-shi, Chiba 263-8522, Japan
}

Received 17 November 2014

\begin{abstract}
Rheometers have been used extensively for evaluating dynamic viscoelasticity of viscoelastic fluids by measuring the stress response to the sinusoidal strain applied to the fluids. It was reported that dynamic viscoelasticity was also derived based on the propagation velocity and the damping ratio of the shear waves propagating in the fluids. In this study, a polarization imaging camera and a particle image velocimetly (PIV) are utilized to visualize shear waves generated by an oscillating plate in a viscoelastic wormlike micellar fluid in order to derive dynamic viscoelasticity. Entangled wormlike micellar fluid of $3.0 \times 10^{-3} \mathrm{~mol} / \mathrm{l}$ cetyltrimethylammonium bromide (CTAB) water solution with additive of sodium salicylate (NaSal) as counter ions at a molar ratio of $S=4$ was used in this study for a test fluid. Propagation velocities were obtained from a sequence of visualized images of propagating waves, which show good agreement to the velocities calculated from the products of wave frequencies and wavelengths. Damping wave profiles were derived from the retardation distributions which were calculated from the captured birefringence images. The dynamic viscoelasticity data derived from the propagation velocities and the damping ratios were in close agreement to the measured data using a rheometer, which shows validity of this method at relatively high frequencies. When the ratio of the amplitude to the wavelength exceeds a critical value, onsets of equilibrium points rising are observed in the damping retardation profiles depending on the amplitude, which attributes to the orientation of micelles on the plate.
\end{abstract}

Key words : Complex fluid, Wormlike micelle, Maxwell fluid, Shear wave, Wave propagation, Birefringence, Particle image velocimetry, Viscoelasticity

1. 緒言

ある種の界面活性剤は，水溶液中で対イオンの添加によりひも状ミセルを形成する。ひも状ミセル水溶液は， 絡み合いにより強い粘弾性を示し，添加する対イオンのモル比によって，粘度や緩和時間などの特性を容易に変 化させることができる特徵のほか, 乱流抵抗低減効果 (トムズ効果) による流体の輸送エネルギーの低減 (Gyr and Bewersdorff, 1995）など有用な特性を示す流体である。ひも状ミセル水溶液はまた，広い周波数領域において，単 一の緩和時間を持つ Maxwell 流体として扱えることが知られている (Kadoma, et. al., 1997).

粘弾性流体は粘性と弾性の両方の性質を持つため，動的なひずみを与える際，変形の時間スケールによって異 なる応答を示す，粘弾性流体の動的な特性を表す物性值として，緩和時間や，貯蔵弾性率および損失弾性率など が用いられており，これらの物性值を知ることは，粘弾性流体を活用する際に非常に重要になってくる.

動的粘弾性の測定には，板の隙間の流体に正弦波的なせん断ひずみを加える gap loading 法に基づく方法が，レ

No.14-00610 [DOI: 10.1299/transjsme.14-00610], J-STAGE Advance Publication date : 23 January, 2015

*1 学生員, 千葉大学大学院 工学研究科（†263-8522 千葉県千葉市稲毛区弥生町 1-33)

*2 正員, 千葉大学大学院 工学研究科

E-mail of corresponding author: fmikami@faculty.chiba-u.jp 
オメータと呼ばれる装置を代表として，広く用いられている。しかし，高周波数域ではせん断波の影響が現れる ため, レオメータで測定できる角周波数の範囲は一般に $\omega \leq 100 \mathrm{rad} / \mathrm{s}$ 程度である. これに対して, 粘弾性流体 中に浸した平板を面内で振動させたときに発生するせん断波の伝播速度と空間的な減衰を調べる surface loading 法に基づく方法は, 比較的高い周波数領域で粘弾性特性を測定することができるので, 時間温度換算則が成立し ないような流体を高周波数域で直接測定する必要がある場合にも有効である. 本研究で測定対象とする臭化セチ ルトリメチルアンモニウム（CTAB）に対イオンとしてサリチル酸ナトリウム（NaSal）を添加したひも状ミセル 水溶液は, 低温では結晶が析出するほか, 温度変化に対してミセル構造が激しく変化するため時間温度換算則を 用いることができない（四方他，1997）。

粘弾性流体中のせん断波の観察には，せん断ひずみにより生じる複屈折のクロスニコル光学系による可視化が これまで用いられており, 瞬時のせん断波の波形解析による貯蔵弾性率と損失弾性率の測定（Ferry, 1980）や, 高速度カメラを用いたせん断波の伝播速度の直接計測（Gladden, et al., 2010, 2012）などが行われてきた. また, surface loading 法の別の例として, 四方ら（1997）は, メカニカルインピーダンスを直接検出する方法を提案して その有効性を示しているが，高精度の測定機器を必要とする.

本研究では, CTAB/NaSal のひも状ミセル水溶液を対象として, 振動平板によって等位相面が平行な平面とな るようなせん断波を粘弾性流体中で発生させ，その空間的な減衰波形と伝播速度を，偏光撮像素子をもつカメラ による複屈折分布の全視野計測によって取得した．また，PIV（Particle Image Velocimetry）によっても断面内の速 度波形を取得した。このとき，せん断波の周期性を利用したサンプリングを行うことで，使用したカメラのフレ 一ムレートよりも高い周波数のせん断波の伝播速度を計測できるようにしている．このような，せん断波の可視 化結果に基づき，貯蔵弾性率および損失弾性率を算出することを試みた。

\section{2. 測定原理}

\section{1 gap loading 法}

粘弾性流体の動的な特性を測定する方法として, 現在広く行われている方法が, レオメータを用いた gap loading 法である.これは, 2 枚の板の隙間に満たされた試料流体に対し, 正弦波的なひずみ（または応力）を入力し， 入力に対する応答である応力（またはひずみ）の振幅と，位相のずれを測定するという方法である.

線形粘弾性流体では, 時間に依存する任意のひずみ $\gamma(t)$ に対する応答は, ステップひずみの重ね合わせと考え ることができ, 時刻 $t$ 応答 $\sigma(t)$ は, 緩和弾性率 $G_{t}(t)$ を用いて,

$$
\sigma(t)=\int_{-\infty}^{t} G_{t}\left(t-t^{\prime}\right) \frac{d \gamma\left(t^{\prime}\right)}{d t^{\prime}} d t^{\prime}
$$

と書ける．試料に正弦波的なひずみ $\gamma=\gamma_{0} \sin \omega t$ を加えたとき， $t-t^{\prime}=s$ とおいて式（1）を用いると，この入 力に対する応答は,

$$
\begin{aligned}
\sigma(t) & =\gamma_{0} \omega \int_{0}^{\infty} G_{t}(s) \cos \{\omega(t-s)\} d s \\
& =\gamma_{0} \omega \int_{0}^{\infty} G_{t}(s)\{\sin (\omega t) \sin (\omega s)+\cos (\omega t) \cos (\omega s)\} d s \\
& =\gamma_{0}\left\{G^{\prime} \sin (\omega t)+G^{\prime \prime} \cos (\omega t)\right\}
\end{aligned}
$$

と表せる。ここで， $G^{\prime}$ は貯蔵弾性率， $G^{\prime \prime}$ は損失弾性率と呼ばれ，粘弾性流体の変形に対する弾性と粘性の影響を 示寸物性值となっている. 式（2）より，

$$
\sigma(t)=\gamma_{0} \sqrt{{G^{\prime 2}}^{2}+G^{\prime 2}} \sin (\omega t+\phi) \quad\left(\sin \phi=\frac{G^{\prime \prime}}{\sqrt{{G^{\prime}}^{2}+G^{\prime 2}}}, \cos \phi=\frac{G^{\prime}}{\sqrt{{G^{\prime 2}}^{2}+G^{\prime 2}}}\right)
$$

となるので, gap loading 法では正弦ひずみに対する応力の振幅比と, 位相のずれ $\phi(0<\phi<\pi / 2)$ を測定するこ とで動的な物性值を算出する事ができる.

ここで, 特に Maxwell モデルでは, $G_{t}(t)=G e^{-t / \tau}$ であるので, 式 (2)より,

$$
G^{\prime}=G \frac{(\omega \tau)^{2}}{1+(\omega \tau)^{2}}, G^{\prime \prime}=G \frac{\omega \tau}{1+(\omega \tau)^{2}}
$$


を得る. Maxwell モデルでは, $\omega \rightarrow \infty$ においてG $\rightarrow G$ となる. 式 (4) より，粘弾性流体が Maxwell モデルによ って記述できる場合, 粘弾性流体の緩和時間 $て$ は,

$$
\tau=\frac{G^{\prime}}{G^{\prime \prime} \omega}=\frac{1}{\omega \tan \phi}
$$

として算出できる.

\section{$2 \cdot 2$ surface loading 法}

前述の gap loading 法とは原理が異なる動的粘弾性測定法として, 粘弾性流体中を伝播するせん断波の伝播速度

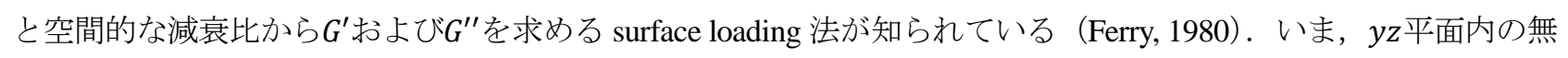
限に広い平板が $y$ 軸の方向に振動しており, $y z$ 平面に平行な平面が等位相面となるようなせん断波が半無限領域 のx軸方向に伝播しているとする。このとき, 微小流体要素に作用する力は, $x y$ 平面上で図 1 のように記述でき る.

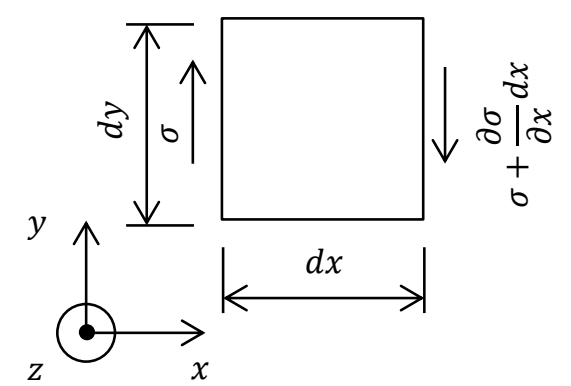

Fig. 1 Stresses acting on a fluid element.

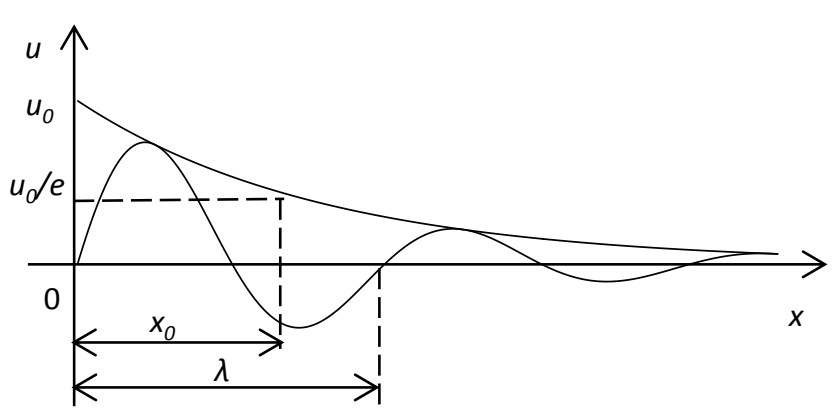

Fig. 2 Instantaneous distribution of a damped shear wave propagating in a viscoelastic fluid. $u$ represents the displacement or the velocity of the waves.

任意の時刻 $t$ と板面からの距離 $x$ での変位を $u(x, t)$ とすると，振幅 $u_{0}$ で正弦波的に振動する板表面 $(x=0)$ では, $u(0, t)=u_{0} \sin (\omega t)$

である. 式（2）より，正弦波的なひずみが入力された時，粘弾性流体内の応力 $\sigma$ は，ひずみとひずみ速度から，

$$
\sigma=G^{\prime} \gamma+\frac{G^{\prime \prime}}{\omega} \frac{d \gamma}{d t}
$$

と表せるので, 流体中の任意の点での応力 $\sigma(x, t)$ は, その点での変位 $u(x, t)$ の勾配を用いて,

$$
\sigma(x, t)=G^{\prime} \frac{\partial u(x, t)}{\partial x}+\frac{G^{\prime \prime}}{\omega} \frac{\partial^{2} u(x, t)}{\partial x \partial t}
$$

と書ける. 図 1 より微小流体要素の運動方程式は, 溶液の密度を $\rho$ として,

$$
\rho \frac{\partial^{2} u(x, t)}{\partial t^{2}} d x d y=\frac{\partial \sigma(x, t)}{\partial x} d x d y
$$

であるので，式（8）および（9）より， $\sigma(x, t)$ を消去すると，

$$
\rho \frac{\partial^{2} u(x, t)}{\partial t^{2}}=G^{\prime} \frac{\partial^{2} u(x, t)}{\partial x^{2}}+\frac{G^{\prime \prime}}{\omega} \frac{\partial^{3} u(x, t)}{\partial x^{2} \partial t}
$$

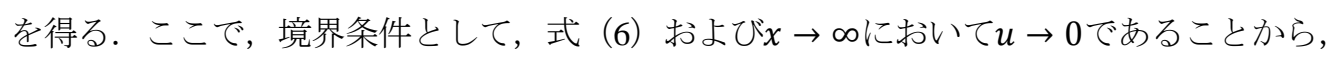

$$
u(x, t)=u_{0} e^{i(\omega t-\Gamma x)}
$$

とおいて式 (10) に代入すると,

$$
\Gamma^{2}=\frac{-\rho \omega^{2}}{G^{\prime}+i G^{\prime \prime}}
$$

を得る。 
式（11）は，「が複素数のとき $x$ 方向に振幅が指数関数的に減衰しながら伝播する波動を表し，ある時刻におけ る流体中の変位uの波形は図 2 のようになる. 図 2 において $x_{0}$ は振幅が $u_{0}$ に対して $u_{0} / e$ に減衰するまでの距離で あり，1/ $x_{0}$ は減衰比と呼ばれる. 図 2 の波動の様式は，図中に示した変数を用いると，

$$
u(x, t)=u_{0} e^{i(\omega t-2 \pi x / \lambda)-x / x_{0}}
$$

と書けるので，式（11）および（12）と比較すると,

$$
\Gamma=\frac{2 \pi}{\lambda}-\frac{i}{x_{0}}=\left(\frac{\rho \omega^{2}}{G^{\prime}+i G^{\prime \prime}}\right)^{1 / 2}
$$

を得る。また，式（13）より，せん断波の伝播速度（位相速度）は $c=\omega \lambda / 2 \pi$ と書け， $r=\lambda / 2 \pi x_{0}$ とおいて整 理すると，

$$
\begin{aligned}
& G^{\prime}=\rho c\left(1-r^{2}\right) /\left(1+r^{2}\right)^{2} \\
& G^{\prime \prime}=2 \rho c^{2} r /\left(1+r^{2}\right)^{2}
\end{aligned}
$$

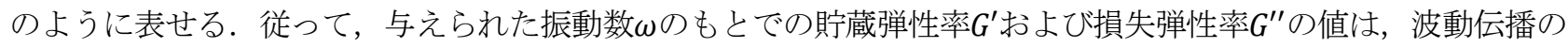
状態の $\left[c, 1 / x_{0}\right]$ または $\left[\lambda, 1 / x_{0}\right]$ の 2 つの量を観測することで算出できる.

また，ひずみは $\gamma=d u / d x$ であるので， $\Gamma$ が $(x, t)$ にらない值であることに注意して，

$$
\gamma=\frac{\partial u(x, t)}{\partial x}=-i \Gamma u_{0} e^{i(\omega t-2 \pi x / \lambda)-x / x_{0}}
$$

となる. 式（17）より，ひずみの減衰波形からも $\left.\lambda ， 1 / x_{0}\right]$ を取得できる.

一方， $y$ 方向の速度を $v=d u / d t$ とすれば，式（13）より，

$$
v=\frac{\partial u(x, t)}{\partial t}=i \omega u_{0} e^{i(\omega t-2 \pi x / \lambda)-x / x_{0}}
$$

であるので，速度の減衰波形は，図 2 において $u=v, u_{0}=v_{0}=\omega u_{0}$ としたものとなり，変位の場合と同じ波長 と減衰比を持つ波形となる。

以上の議論から，粘弾性流体中を伝播するひずみまたは速度波形について，動画像と瞬時の波形から伝播速度

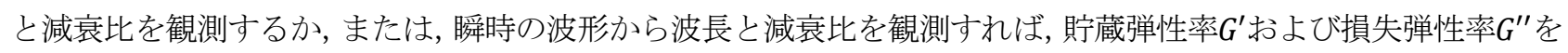
算出することができる，このためには，流体中を伝播するせん断波における，ひずみ分布および速度分布を可視 化する手法が必要となる.

\section{$2 \cdot 3$ 可視化手法}

せん断波におけるひずみ分布の取得には，流動複屈折を用いた．ひも状ミセルは軸方向と半径方向で分極率が 異なるため, 流動に起因寸る異方性を持つひも状ミセルのネットワーク内では, 複屈折が起こる. この複屈折に よるリタデーション $\delta$ のきさは，配向角が一定の場合は光学弾性則より $\sigma \propto \delta$ の関係が成り立つ（Shikata, et. al., 1994）ので, 微小流体要素に働く応力 $\sigma$ と比例し, リタデーションの分布と応力分布が対応する. また，式 (3) より応力の減衰波形はひずみの減衰波形に対して位相が申だけ異なるが，伝播速度および減衰比が等しい波形と なる.このことから，リタデーションの波動伝播の状態を解析することで，ひずみの減衰波形における $\left[c, 1 / x_{0}\right]$ または $\left[\lambda ， 1 / x_{0}\right]$ を取得できることがわかる.

本研究では, 偏光状態が既知の光をせん断波の波面に平行に入射し, 透過光の偏光状態の変化を偏光撮像素子 で撮影して画像として計測することによって, 図2 のようなリタデーションの減衰波形を得た。一方, 速度波形 の取得には，PIVを用いた．PIVの測定ではレーザーシート光を照射した断面内の情報が得られるのに対して， 流動複屈折による測定では, 試料溶液中を光線が通過した距離での平均值としての情報が得られるという違いが ある。

\section{3. 実験および方法}

\section{$3 \cdot 1$ 試料溶液}

試料溶液は，臭化セチルトリメチルアンモニウム（CTAB）と対イオンとしてサリチル酸ナトリウム（NaSal） を脱イオン水に溶解して作成し, $25^{\circ} \mathrm{C} て ゙ 24$ 時間以上静置した. 本研究では CTAB のモル濃度 $C_{D} を C_{D}=30 \times$ 


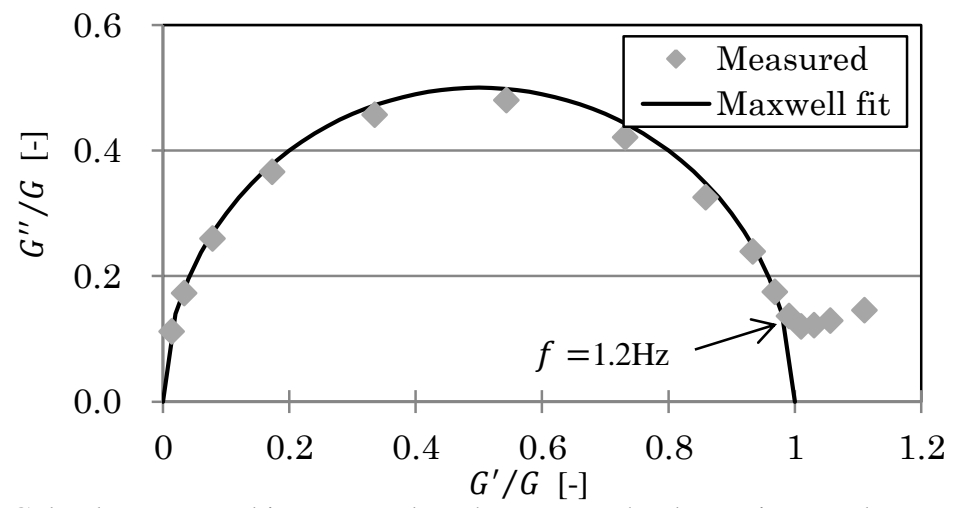

Fig. 3 Cole-Cole plot measured in a cone-plate rheometer. The data points produce a semicircular relationship in $f \leq 1.2 \mathrm{~Hz}$, indicating that this fluid can be described by the single mode Maxwell model.

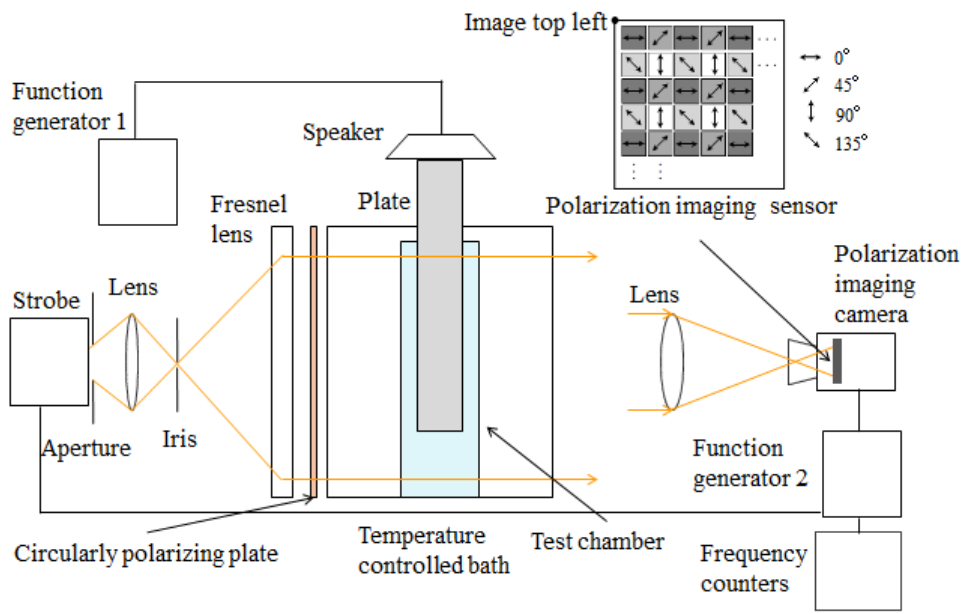

(a) Flow birefringence measurements.

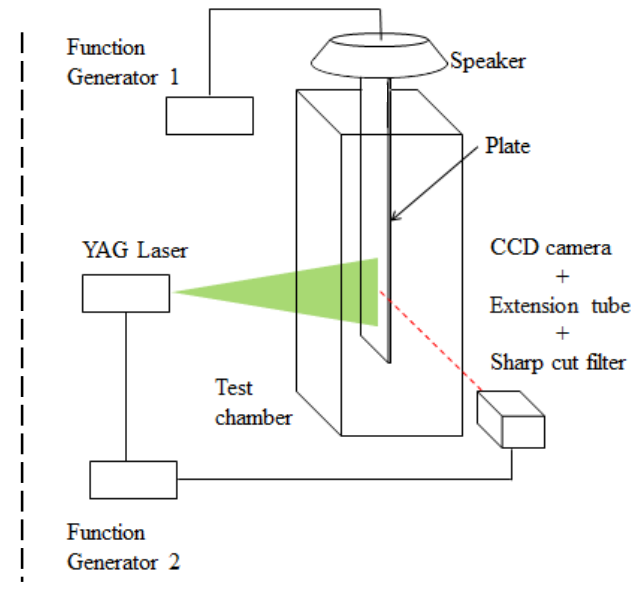

(b) PIV measurements.

Fig. 4 Schematic diagram of experimental setup.

$10^{-3} \mathrm{~mol} / \mathrm{l}$ とし， NaSal のモル濃度 $C_{S}$ のモル比 $S か ゙ ， S=C_{S} / C_{D}=4$ の溶液を用いた.

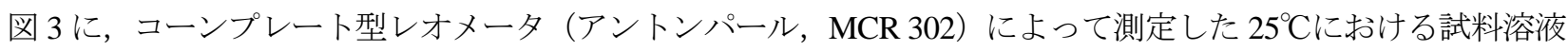
の Cole-Cole プロットを示す. 図 3 の半円で近似できる $f<1.2 \mathrm{~Hz}$ の範囲においては, 試料溶液は, 単一緩和時間 を持つ Maxwell 流体とみなせることがわかる.

\section{$3 \cdot 2$ 実験装置}

実験装置の概略を図 4 に示寸. 透明アクリルキャスト板製の直方体容器（100×100×320 mm）内に試料溶液を 満たし, 恒温水槽で液温を $25{ }^{\circ} \mathrm{C} に$ 保った。 実験前に試料溶液を摚挥し，静置した後，スピーカ（Fostex，開口寸 法 $94 \mathrm{~mm}$ ，インピーダンス $8 \Omega$ ）の振動面と接続されたポリスチレン製の振動板（60×180×1 mm）を図 4 のよ うに板が鉛直になるようにして，容器中央に設置した，振動板の質量は，接続部を含め $21.5 \mathrm{~g}$ であった．ファン クションジェネレータ 1 に直接接続されたスピーカを正弦波で駆動し，振動板を $6 \sim 30 \mathrm{~Hz}$ の範囲で板の面内で振 動させることで, 試料溶液内にせん断波を発生させた. 図 4 の配置において，せん断波は振動板に対して垂直な 方向に伝播し，せん断波の等位相面は振動板と平行な平面となる. 振動板の振幅は，スピーカの入力電圧によっ て変化させた．なお，PIV 計測における振動板先端および板面上のトレーサ粒子の軌跡より，振動板が十分な精 度で正弦波的に振動していることを確認した。

試料溶液のリタデーションの測定には, 図 4 (a) に示すような偏光撮像素子をもつ偏光イメージングカメラ ( オトニックラティス，PI-100， $1120 \times 868$ pixel）を用いた. 照明に用いるストロボ光は，フレネルレンズ（焦点距 離 $650 \mathrm{~mm}$ ）を通過後平行光となり円偏光板によって左回り円偏光となった後, 試料溶液に入射する. 試料溶液 中の, せん断波を透過した光は，カメラ前方の集光レンズによってレーザラインフィルタ（コヒレント社，中心 波長 $533.1 \mathrm{~nm}$, 半値全幅 $8.9 \mathrm{~nm}$ ）を取り付けた撮影レンズ（ニコン, Ai AF MICRO NIKKOR 60mm f/2.8D）の直 
前で焦点を結んだ後，撮像面へ到る. カメラとストロボは，ファンクションジェネレータ 2 を用いて撮影周波数 $2 \sim 5 \mathrm{~Hz}$ の範囲で同期させた.

PIV 計測では, トレーサ粒子として, アクリル絵具（ターナー色彩, 蛍光レッド 206）を試料溶液中に混入し た. 照明には Nd:YAG レーザ $(532 \mathrm{~nm}, 30 \mathrm{~mJ} / \mathrm{pulse}$ ）のシート光（シート厚み $0.8 \mathrm{~mm}$ ）を用いて, 振動板に垂直 な断面内の流れを，トレーサ粒子の蛍光のみを透過させるシャープカットフィルタ（O56）と撮影レンズ（ニコ ン, NIKKOR 50mm）を装着した CMOS カメラ（Adimec，4150m/1C，2304×1728 pixel）で撮影した. カメラと レーザーは，ファンクションジェネレータ 2 を用いて $0.1 \sim 15 \mathrm{~Hz}$ の範囲で同期させ，撮影した画像から直接相互 相関法を用いて速度場を算出した。

\section{$3 \cdot 3$ 偏光イメージングカメラ}

偏光イメージングカメラでは, 図 4(a)に示すような, 撮像素子の前方に取り付けられている, $0^{\circ}, 45^{\circ}, 90^{\circ}, 135^{\circ}$ の 4 方向の直線偏光板アレイを透過した画像から, 双一次補間によって各方向の直線偏光板を透過したときの光強 度を同時に 4 枚の画像として取得することができる.このため, 時間的に変化する偏光状態にも適用可能である.

偏光状態を記述寸る方法としてストークスパラメータ $S_{0}, S_{1}, S_{2}, S_{3}$ が用いられる. ストークスパラメータは実験 によって測定可能な光の強度で表現され，このうちの $S_{0}, S_{1}, S_{2}$ の 3 つが，偏光イメージングカメラによって観測 された輝度值から，

$$
\left\{\begin{array}{l}
S_{0}=I_{0}+I_{90} \\
S_{1}=I_{0}-I_{90} \\
S_{2}=I_{45}-I_{135}
\end{array}\right.
$$

のようにして求まる.ここで, $I_{0}, I_{45}, I_{90}, I_{135}$ は, $0^{\circ}, 45^{\circ}, 90^{\circ}, 135^{\circ}$ の直線偏光板を透過した画像上の同じ位置にあ る画素の輝度值である. さらに, 電場べクトルの直線偏光度DOLP (Degree Of Linear Polarization) と偏光方位角 $A O P$ (Angle Of Polarization) がストークスパラメータを用いて,

$$
\begin{aligned}
& D O L P=\frac{\sqrt{S_{1}{ }^{2}+S_{2}{ }^{2}}}{S_{0}} \\
& A O P=\frac{1}{2} \tan ^{-1} \frac{S_{2}}{S_{1}}
\end{aligned}
$$

のように表され, 偏光状態の画像表示に用いられる. DOLPの值は, 円偏光の光では 0\%, 直線偏光の光では $100 \%$ となり, せん断波による複屈折で生じる透過光の円偏光からの変化量をDOLPの值によって観測して, 画像上の 明度として可視化した. なお, カメラの光学系の特性上DOLPの最大值は約 $70 \%$ として測定されるため, 最大值 が 100\%になるように規格化を行った。 また, 減衰波形の解析には, 次節で述べるように, DOLPの值から計算さ れるリタデーションを用いる.

\section{$3-4$ リタデーションと進相軸方位}

入射光と透過光における偏光状態の関係は, ストークスパラメータを縦に並ベた 4 次元のストークスベクトル $\boldsymbol{S}=\left[S_{0} S_{1} S_{2} S_{3}\right]^{\mathrm{T}}$ と試料のミュラー行列 $\boldsymbol{M}$ によって,

$$
S_{t}=M S_{i}
$$

と表せる. ここで， $\boldsymbol{S}_{\boldsymbol{i}}$ および $\boldsymbol{S}_{\boldsymbol{t}}$ は，それぞれ入射光と透過光のストークスベクトルである. 複屈折性を示寸試料 のミュラー行列は，試料の厚さで空間平均したリタデーション $\bar{\delta}$ と進相軸方位角 $\bar{\chi}$ 用いて，

$$
\boldsymbol{M}=\left[\begin{array}{cccc}
1 & 0 & 0 & 0 \\
0 & \cos ^{2} 2 \bar{\chi}+\sin ^{2} 2 \bar{\chi} \cos \bar{\delta} & \cos 2 \bar{\chi} \sin 2 \bar{\chi}(1-\cos \bar{\delta}) & -\sin 2 \bar{\chi} \sin \bar{\delta} \\
0 & \cos 2 \bar{\chi} \sin 2 \bar{\chi}(1-\cos \bar{\delta}) & \sin ^{2} 2 \bar{\chi}+\cos ^{2} 2 \bar{\chi} \cos \bar{\delta} & \cos 2 \bar{\chi} \sin \bar{\delta} \\
0 & \sin 2 \bar{\chi} \sin \bar{\delta} & -\cos 2 \bar{\chi} \sin \bar{\delta} & \cos \bar{\delta}
\end{array}\right]
$$

と表せる (Galante and Frattini, 1991)．入射光が左回りの円偏光 $\boldsymbol{S}_{\boldsymbol{i}}=\left[\begin{array}{llll}1 & 0 & 0 & -1\end{array}\right]^{\mathrm{T}}$ のとき，式（22）を使って 透過光の偏光状態 $\boldsymbol{S}_{\boldsymbol{t}}$ を計算すれば，（20）および（21）より， 


$$
\left\{\begin{array}{l}
|\bar{\delta}|=\sin ^{-1}(D O L P) \\
\bar{\chi}=A O P+\frac{\pi}{4}
\end{array}\right.
$$

の関係が得られる.

偏光イメージングカメラによる測定結果には，せん断波による複屈折の他に，実験装置を光が通過する際の複 屈折や, 偏光撮像素子の偏光子アレイの各方向の感度の違いによる影響などが混在している. 本研究では, これ

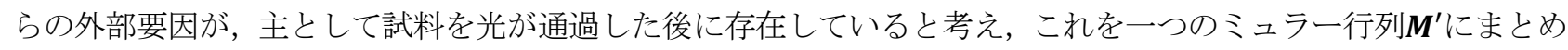
て補償を試みた。

まず，せん断波を発生させない状態（せん断波による複屈折が発生しないため $\boldsymbol{M}=\boldsymbol{E}, \boldsymbol{E}$ は単位行列）での透 過光を測定する. このとき, 入射光のストークスベクトル $\boldsymbol{S}_{i}$ と, 実際に測定される透過光のストークスベクトル $\boldsymbol{S}_{\boldsymbol{t}}$ の関係は,

$$
S_{t}=M^{\prime} E S_{i}
$$

とかける. 画像上の領域内の輝度 $I_{0}, I_{45}, I_{90}, I_{135}$ の平均值を用いて, 式（19）から透過光の平均值としてのストー クスパラメータ $S_{0}, S_{1}, S_{2}$ を求めた. さらに, 直接計測することができない $S_{3}$ にいては偏光状態が入射光と同じ ように左回りの完全偏光であると仮定して,

$$
S_{3}=-\sqrt{S_{0}{ }^{2}-S_{1}{ }^{2}-S_{2}{ }^{2}}
$$

の関係から求めた．本研究では，入射光が左回りの円偏光であることから $\boldsymbol{S}_{\boldsymbol{i}}=\left[\begin{array}{llll}1 & 0 & 0 & -1\end{array}\right]^{\mathrm{T}}$ のように既知と なるので, 観測した $\boldsymbol{S}_{\boldsymbol{t}}$ と, 式（23）および（25）を用いて外部要因のミュラー行列 $\boldsymbol{M}^{\prime}$ の各要素の值を算出した.

つぎに，せん断波を発生させ，せん断波を透過した光のストークスベクトルを取得した．このとき，透過光の ストークスベクトルは，本研究の仮定では試料を光が通過した後に外部要因の影響があることに注意して，

$$
S_{t}=M^{\prime} M S_{i}
$$

と表せる. ミュラー行列 $\boldsymbol{M}^{\prime}$ の逆行列を, 計測された透過光のストークスベクトル $\boldsymbol{S}_{\boldsymbol{t}}$ に左側からかけることで, 外 部要因によって発生する複屈折の影響を補償した透過光のストークスベクトルを得ることができる. 補償後のス トークスパラメータを用いて式（20）から直線偏光度DOLPの計算および規格化を行い，式（24）より複屈折の リタデーション $|\bar{\delta}|$ を算出した. なお，以後は簡単のため， $|\bar{\delta}|$ の代わりに $|\delta|$ を使って表す.

\section{$3 \cdot 5$ 撮影方法}

Gladden ら（2010，2012）は, ハイスピードカメラを用いてせん断波の伝播速度を直接計測しているが, 本研 究では, せん断波の周期性を利用してカメラのフレームレートをせん断波の周波数に合わせて調整し, 数周期後 の位相が少しずつずれた画像をサンプリングすることで，八イスピードカメラなどを用いずに，カメラのフレー ムレートよりも周波数の高いせん断波の伝播を観測できるように工夫した. 本研究で測定したせん断波の周波数 範囲は数 $\mathrm{Hz}$ 数十 $\mathrm{Hz}$ であるが, 偏光撮影では $2 \sim 5 \mathrm{~Hz}, \mathrm{PIV}$ 撮影では $0.1 \sim 15 \mathrm{~Hz}$ の範囲で撮影を行った.

せん断波の周波数を $f$, カメラのフレームレートを $f_{c}$ とすると, せん断波の 1 周期を $n$ 等分した画像を得るため には, $a>0 と b>0$ を任意の整数として,

$$
f_{c}=\left(\frac{b}{n f}+\frac{a}{f}\right)^{-1}
$$

の関係を満たす必要がある.ここで, $f_{c}$ がカメラで設定可能なフレームレートの範囲になるように注意して,$a$ と $b$ 值を選定した. なお, 撮影結果は, $b$ 枚ごとに, 周波数を $n$ 等分した連続画像として取得できる $\left(f>f_{c}\right.$ では, $b=1$ でよい). この方法により, 擬似的にフレームレートがnfのカメラで撮影した画像を得ることができる.

$|\delta|$ の波形の最小值 (等位相面) が連続する画像の 2 時刻間に移動した距離を $d$ とすると, 伝播速度 $c$ は, 式 (28) の $a$ 用いて,

$$
c=\frac{d f}{\left(f / f_{c}-a\right)}
$$

より算出できる. この方法で直接算出した伝播速度と, 周波数と波長の積から求めた伝播速度の比較を行った. 


\section{$3 \cdot 6$ 波形の解析方法}

偏光撮影では, 撮影領域内の各画素で取得した $|\delta|$ の值を, 板に沿う方向に平均化することで, 板からの距離 $x に$ 対するリタデーション $|\delta|$ の值をプロットした波形データを得た. 2 ・2 節で述べた方法によって貯蔵弾性率およ び損失弾性率を算出するため，計測によって得られた波形から，非線形の最小二乗法による曲線のあてはめを用 いて，せん断波の減衰波形を表すパラメータを得た。非線形の最小二乗法の反復計算には一般化簡約勾配法

（Generalized Reduced Gradient method）を用いた．図 2 の変数を用いると，任意の時刻で，せん断波によるリタ デーションの值の平衡点からの変化量の絶対值 $|\delta|$ は, 板表面を $x=0$, その時刻での位相のずれを $2 \pi x^{\prime} / \lambda$ として,

$$
|\delta|=\delta_{0} e^{-x / x_{0}}\left|\sin \left\{-2 \pi\left(x-x^{\prime}\right) / \lambda\right\}\right|
$$

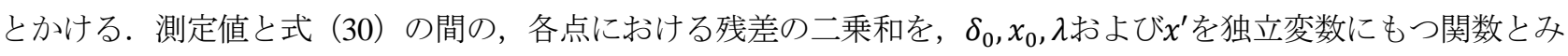

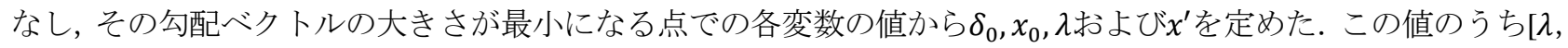

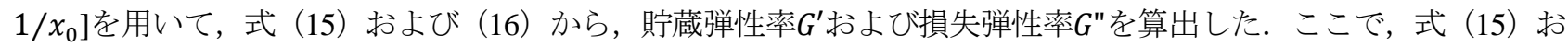
よび（16）が示寸通り，本研究における測定法では，板の寸法は影響しない．また，同様にして PIV 計測から得 られた板面に沿う方向の速度成分vの波形についても，式（18）に基づいて解析を行った.

\section{4. 結果および考察}

\section{$4 \cdot 1$ 偏光による可視化結果}

振動数 $f=10 \mathrm{~Hz}$ において発生したせん断波の直線偏光度DOLPによる瞬時の可視化画像を図 5 に示す.撮影時の

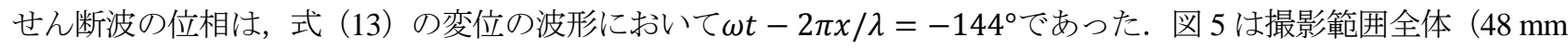
$\times 37 \mathrm{~mm}$ ）を示しており，振動板の下端を除いて，板に平行な等位相面をもつせん断波を明暗の縞として確認で きる. また, 板から遠ざかるにつれてせん断波は十分減衰しており, 容器壁からの反射の影響も見られない.

DOLPの值を規格化し, 式 (24) よりリタデーション $|\delta|$ を算出した結果について, ミュラー行列を用いた補償 前後の $|\delta|$ の值と, 補償後の $|\delta|$ より求めた波形の近似曲線および減衰曲線を図 6 に示寸. 本来 $|\delta|$ の波形は減衰波 形の絶対值として測定されるはずであるが, 補償前の $|\delta|$ は一様な減衰率で減衰寸る波形となっていなかった。 こ れは，3・4節で述べたように，せん断波による複屈折と，それ以外の要因で発生する複屈折の影響が重なり合っ ていたためである. 図6の補償後の波形からわかる通り，ミュラー行列を用いた補償によって，外部要因による 複屈折の影響を取り除くことができている. なお，板表面からの距離が大きくなるにつれてせん断波のリタデー ションが減衰してゼロに近くなり，相対的にノイズの割合が増加するため, リタデーションの測定領域は, 比較 的振幅の大きい板表面から $15 \mathrm{~mm}$ までの, 図 5 中に緑線枠で示した範囲とし, そのy方向の空間平均を取得した.

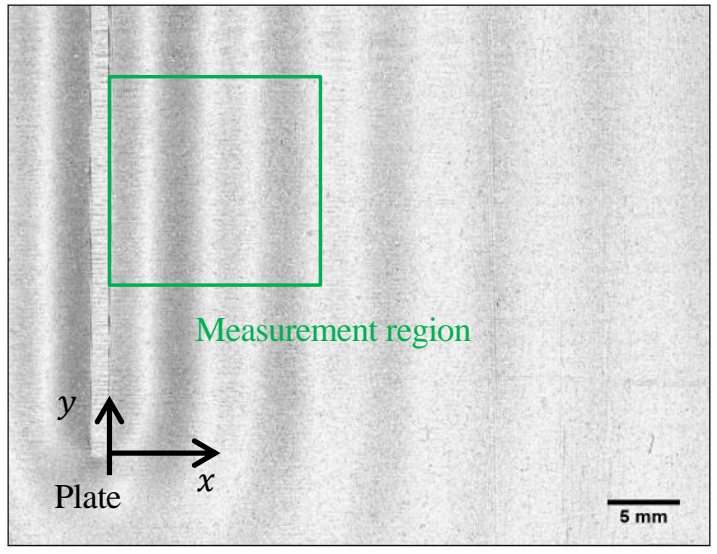

Fig. 5 Visualization of a propagating shear wave ( $f=10 \mathrm{~Hz}$ ). Dark lines indicate higher DOLP which correspond to equiphase lines of the shear wave. Measurement region of retardation is shown as a green box $(0 \leq x \leq 15 \mathrm{~mm})$.

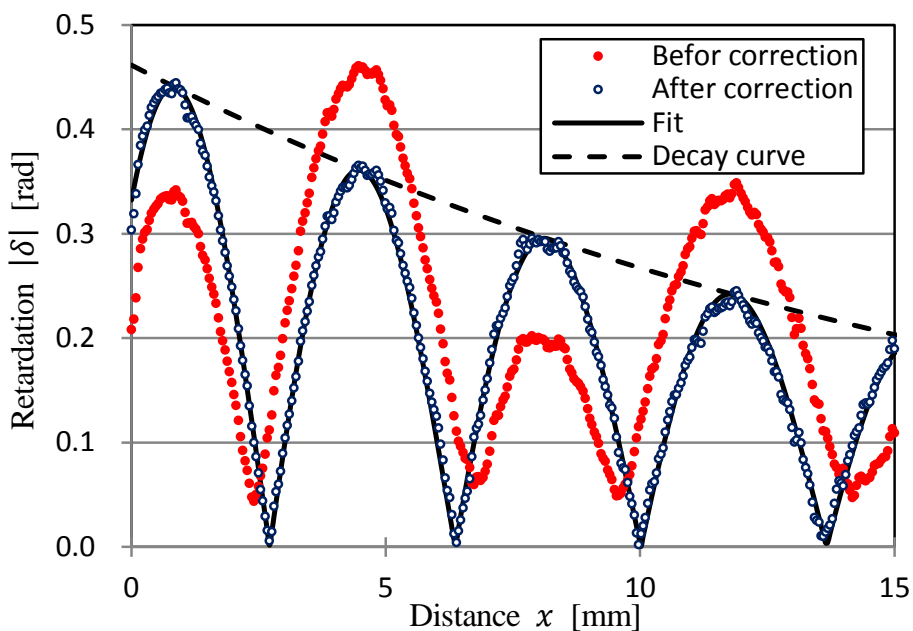

Fig. 6 Spatial averaged retardation measured in the area shown as a green box in Fig. 5 and fitting of a damped shear wave as a function of distance $(f=10 \mathrm{~Hz})$. Corrected data using Mueller matrix produce a decay curve. 


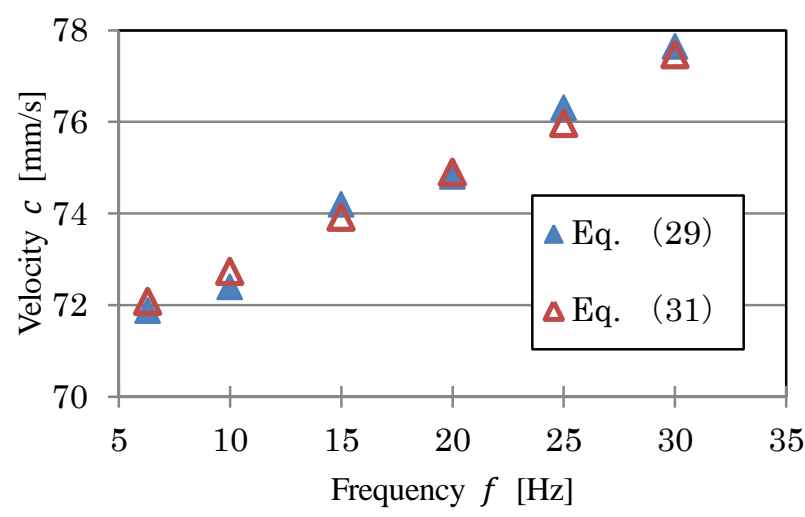

Fig. 7 Propagation velocities of shear wave vs frequency. These velocities are not constant as expected from Maxwell model but increasing with frequencies.

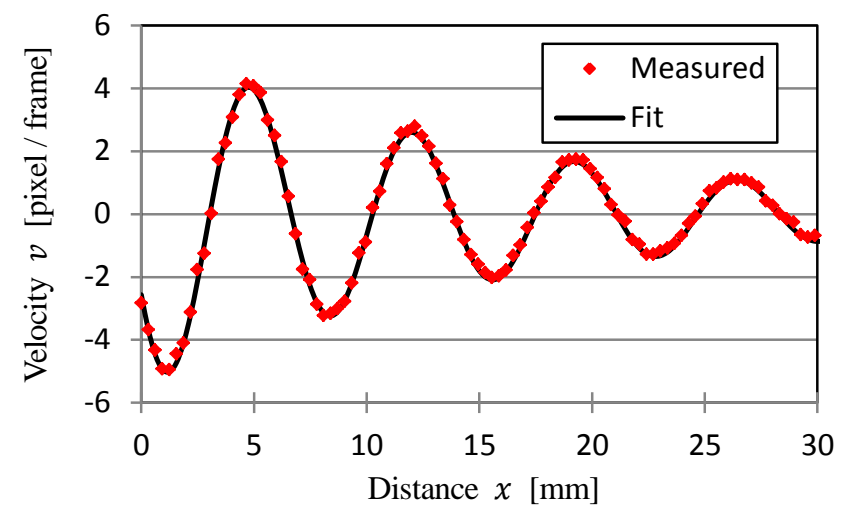

Fig. 8 Spatial averaged velocities obtained by the PIV measurement and fitting of a damped shear wave as a function of distance $(f=10 \mathrm{~Hz})$.

\section{$4 \cdot 2$ せん断波の伝播速度}

$f=6.3 \sim 30 \mathrm{~Hz}$ の範囲において, 偏光による可視化結果に基づき, カメラのフレームレートから式（29）によっ て算出した伝播速度と, せん断波の周波数および波長から, 次式

$$
c=f \lambda
$$

によって求めた伝播速度を, 図 7 に示す. 両者は $1 \%$ 程度の差で一致したため, 八イスピードカメラなどを用い なくとも，3・5 節に示した撮影方法によって試料流体中を伝播するせん断波の伝播速度を正確に測定できること を確認した.

Maxwell モデルでは，せん断波の伝播速度は周波数によらず一定值であり，式（4）のGと，流体の密度 $\rho$ を用 いて,

$$
c=\sqrt{G / \rho}
$$

となるが, 図 3 からわかるように, 図 7 に示した 6.3 30 Hz の測定範囲は Maxwell モデルで表せる範囲 $(f<1.2 \mathrm{~Hz})$ を超えており，せん断波の伝播速度は， $71.9 \mathrm{~mm} / \mathrm{s}$ から $77.7 \mathrm{~mm} / \mathrm{s}$ まで周波数の上昇と共に緩やかに増加した。 こ の結果は, 次節で示寸貯蔵弾性率 $G^{\prime}$ の上昇にも対応している. また, 測定時の振動板の振幅は 0.05 0.3 mm 程度 のため，この測定範囲では，板の運動速度はせん断波の伝播速度よりも小さい.

\section{4 - 3 動的粘弾性測定結果}

図 6 に示すリタデーションの減衰波形の絶対值の測定結果に基づき，式（30）から，3・6 節で示した最小二乗

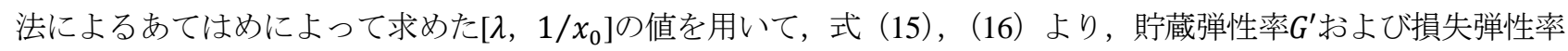
$G^{\prime \prime}$ を算出した。 また, 図 8 には, PIV 計測により求めた速度分布の減衰波形と式（18）による近似曲線を示寸. 相互相関法PIVでのピーク位置のサブピクセル補間によって, 1 ピクセル以下の精度で減衰波形が得られている. 速度波形の解析では，せん断波の伝播方向により多くの測定点を確保するため，板表面から $30 \mathrm{~mm}$ までを計算領 域と定めた. 速度分布の波形からも同様に， $\left[\lambda ， 1 / x_{0}\right]$ の值を求めて， $G^{\prime}$ および $G^{\prime \prime}$ を算出した。測定值の精度を検

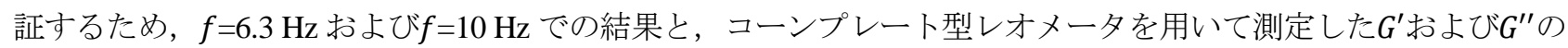
值を表 1 に示寸. 偏光計測および PIV の測定結果は, 10 時刻分の平均值と標準偏差が示されている. 表 1 より,

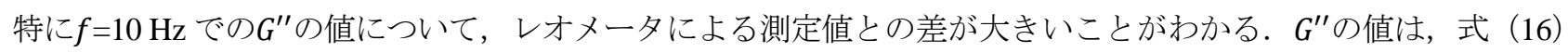
から示されるように, 減衰比の影響を大きく受けるので, 精度向上にはより精密な減衰比の測定が必要となる.

レオメータによる測定值と, 本研究による $f=6.3 \sim 30 \mathrm{~Hz}$ における測定值を重ねて図 9 に示す. 本実験では, レ オメータによる測定限界を超える周波数範囲を測定できているが， Maxwell モデルの適用を超える範囲であるた め， $G^{\prime}$ は Maxwell モデルにおけるGに漸近せず，周波数の上昇とともにさらに増加している. 図 3 からわかる通 り，本実験で使用した試験流体を Maxwell モデルに近似して緩和時間を算出するためには，より低い周波数領域

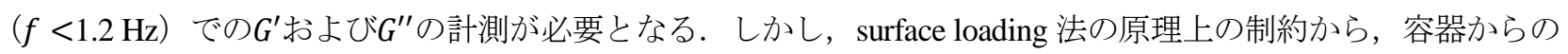
反射波が撮影範囲に到達すると減衰波形の正確な評価を行えない，減衰が小さく波長が長い低い周波数での測定 
Table 1 Comparison of viscoelastic moduli measured by the present method and a rheometer (average $\pm S . D$.)

\begin{tabular}{|l|r|r|r||r|r|r|r|}
\hline \multicolumn{4}{|c||}{$f=6.3 \mathrm{~Hz}$} & \multicolumn{4}{c|}{$f=10 \mathrm{~Hz}$} \\
\hline \hline & Polarization imaging & Rheometer & Difference & & Polarization imaging & Rheometer & Difference \\
\hline$G^{\prime}$ & $5.30 \pm 0.06 \mathrm{~Pa}$ & $5.00 \mathrm{~Pa}$ & $6.0 \%$ & $G^{\prime}$ & $5.36 \pm 0.02 \mathrm{~Pa}$ & $5.25 \mathrm{~Pa}$ & $2.1 \%$ \\
\hline$G^{\prime \prime}$ & $0.61 \pm 0.04 \mathrm{~Pa}$ & $0.61 \mathrm{~Pa}$ & $0.0 \%$ & $G^{\prime \prime}$ & $0.78 \pm 0.02 \mathrm{~Pa}$ & $0.69 \mathrm{~Pa}$ & $13.0 \%$ \\
\hline \hline & $\mathrm{PIV}$ & Rheometer & Difference & & PIV & Rheometer & Difference \\
\hline$G^{\prime}$ & $5.24 \pm 0.08 \mathrm{~Pa}$ & $5.00 \mathrm{~Pa}$ & $4.8 \%$ & $G^{\prime}$ & $5.28 \pm 0.03 \mathrm{~Pa}$ & $5.25 \mathrm{~Pa}$ & $0.6 \%$ \\
\hline$G^{\prime \prime}$ & $0.58 \pm 0.08 \mathrm{~Pa}$ & $0.61 \mathrm{~Pa}$ & $4.9 \%$ & $G^{\prime \prime}$ & $0.73 \pm 0.03 \mathrm{~Pa}$ & $0.69 \mathrm{~Pa}$ & $5.8 \%$ \\
\hline
\end{tabular}

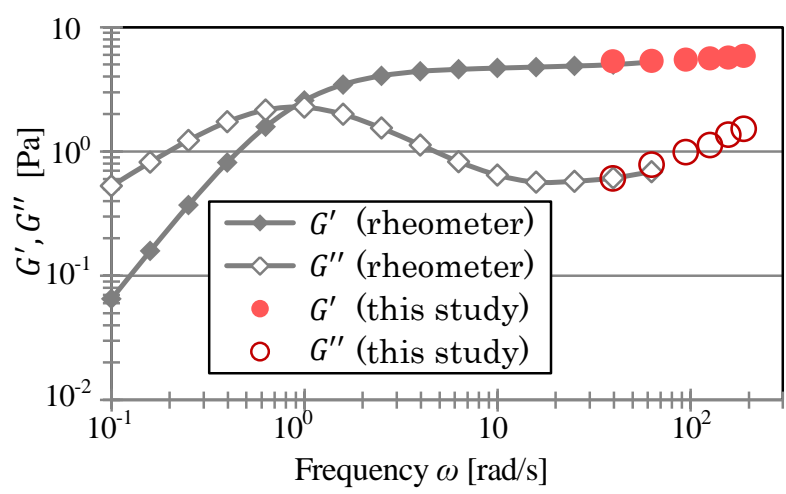

Fig. 9 Storage and loss shear moduli measured by a rheometer and the present method. The data in the higher frequency ranges, $\omega \geq 10^{2} \mathrm{rad} / \mathrm{s}$, are obtained by this method.

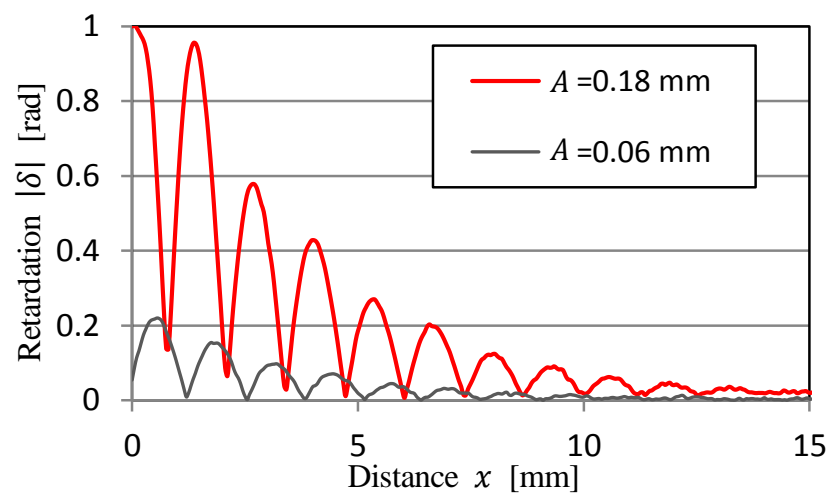

Fig. 10 Effect of amplitude on equilibrium points rising in damping shear waves ( $f=30 \mathrm{~Hz}$ ). Rising of equilibrium points is observed at higher amplitude.

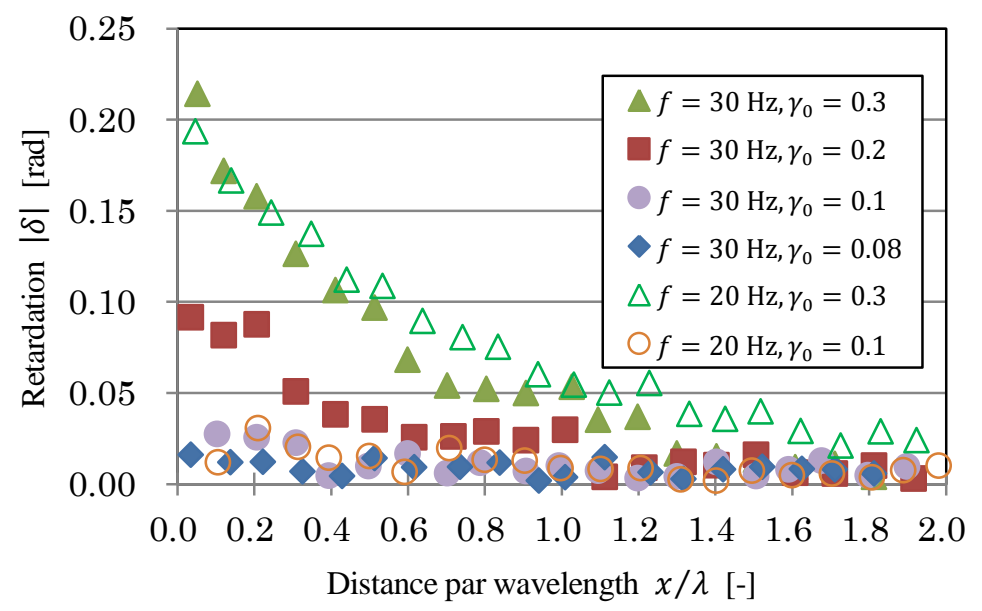

Fig. 11 Effect of amplitude par wavelength on rising of equilibrium points. When the ratio of amplitude to wavelength $\left(\gamma_{0}=A /(\lambda / 4)\right)$ exceeds the critical value ( $\gamma_{0} \fallingdotseq 0.1$ ), rising of equilibrium points is observed.

には，十分な減衰を確保するために容器壁まで長い距離が必要となる（Ferry, 1980, 四方他, 1997). このため, 本実験装置では $f=6 \mathrm{~Hz}$ よりも低い周波数での観測は困難であった。この問題を解決するためには，より大きな試 験容器と，その容器を満たすのに十分な量の試験流体を用意する必要がある.

\section{$4 \cdot 4$ 振幅の大小による測定值への影響}

本研究で使用したひも状ミセル水溶液において, せん断波の振幅を徐々に大きくしていくと, 観測される| $\delta \mid の$ 極小值である平衡点が，板に近づくにつれ上昇するという現象が観測された. 図 10 に $f=30 \mathrm{~Hz}$ における，振動板 の振幅 $A$ のきさが, $A=0.18 \mathrm{~mm}$ の場合と, $A=0.06 \mathrm{~mm}$ の場合での, $|\delta|$ の平衡点の変化を示す. 図 10 より, 振 


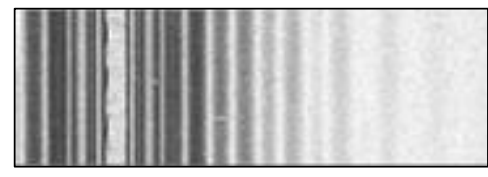

(a) $t=-0.2 \mathrm{~s}$

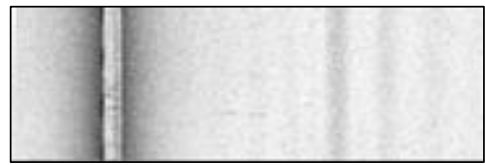

(b) $t=0.0$

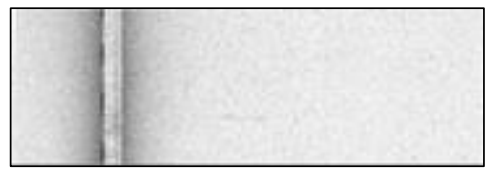

(c) $t=0.8$

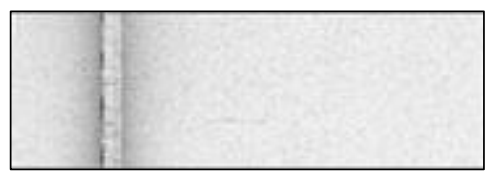

(d) $t=1.6$

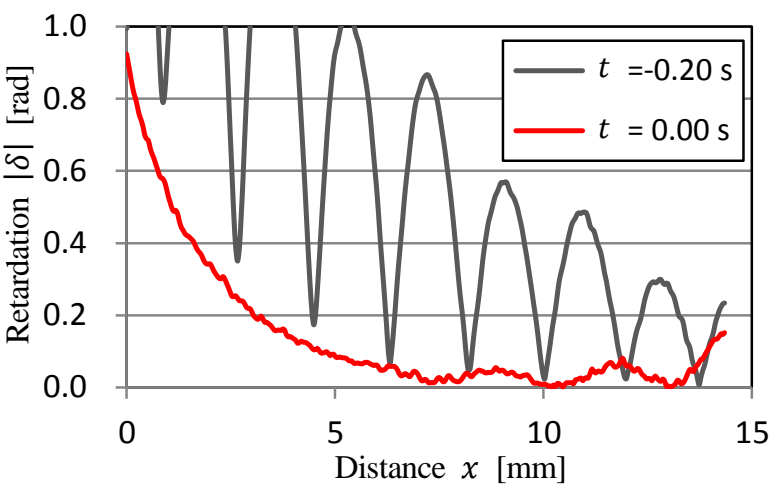

(e) Retardation

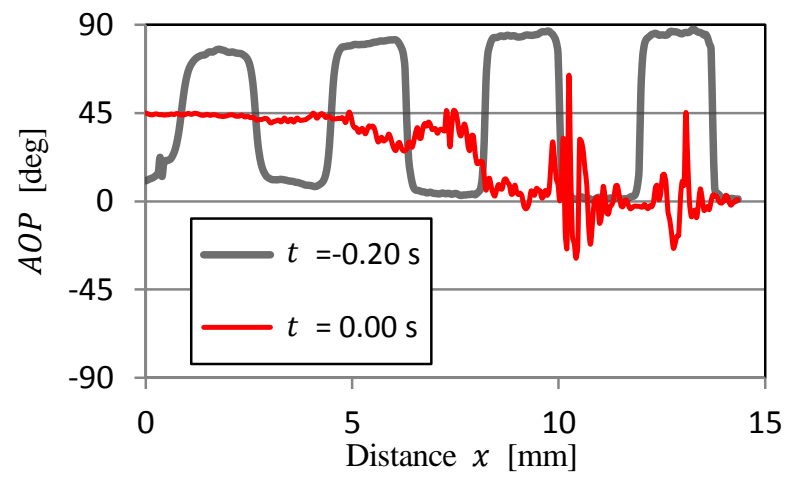

(f) $A O P$

Fig. 12 Temporal change of polarization after sudden stop of the plate oscillating at a large amplitude $(f=20 \mathrm{~Hz})$. The plate stops at $t=0.0 \mathrm{~s}$ after enough oscillating time. The area with high DOLP (dark regions) remains on the plate, and the area reduces with time $(\mathrm{a} \sim \mathrm{d})$. This high $D O L P$ area corresponds to the equilibrium points rising (e). The angle of fast axis in this area is $\chi=0^{\circ}$ judging from the measured value of $A O P=45^{\circ}$, indicating that wormlike micelles orient parallel to the plate (f).

幅 $A$ が大きい波形について，板近傍で $|\delta|$ の平衡点が上昇していることがわかる．このような， $|\delta|$ の平衡点が 0 で ない曲線からは正確な減衰曲線を得ることができなかった，そのため，本研究の計測方法では， $|\delta|$ の平衡点が上 昇する現象が発生しない程度に小さい振幅を選定する必要があった.

平衡点の上昇が起こる振幅はせん断波の周波数により異なるため, 振動板の振幅 $A$ と波長 $\lambda$ より， $\gamma_{0}=A /(\lambda / 4)$ により見積もった板表面でのひずみ量の最大值 $\gamma_{0}$ で整理した. 図 11 に, 振動板の振幅と周波数を変化させたとき の 5 時刻分の平衡点の推移をプロットしたグラフを示す，板から離れた，影響がない領域での平衡点のばらつき 量を閾値とし，その值を超える変化を平衡点の上昇と判断した. 図 11 より，平衡点の上昇は，板表面でのひずみ 量の最大值が一定値（本研究で使用した溶液では， $\gamma_{0} \fallingdotseq 0.1$ ）を超えると顕著に現れることがわかった.

この現象に対し，ミセルの配向の観点から考察を行う. 図 12 に，平衡点の上昇が発生する振幅で振動させたの ち，板を停止させたときの，板近傍の偏光状態の時間変化を示す． $t=0.0 \mathrm{~s}$ で振動板が突然停止した際，板近 傍にDOLPが周囲に比べて大きい領域が残存し，その領域が時間経過とともに徐々に減少していくことが図 12

（a d）からわかる．この板近傍に見られるDOLPが大きい領域により，平衡点の上昇が起きたことが，振動板を 停止する前後の波形（図 12 (e) ) を比べることによりわかる。 なお図 12 (e) では，対応する図 12 (a)，(b) で, DOLPが 100 \%を超えない $(|\delta| \leq \pi / 2)$ 範囲の夕を示している.

板から離れた振幅が十分に小さい範囲では, 図 12 (f) の振動時の $A O P$ の值は半波長ごとに $0^{\circ}$ と $90^{\circ}$ を繰り返す. ひも状ミセルでは軸方向が進相軸，半径方向が遅相軸となる（Shikata, et al., 1994）ので，平衡点の上昇が起こら ない通常の振動時には，式（24）より求まる進相軸方位 $の$ の值から，せん断力によるせん断変形の向きによって ミセルが $45^{\circ}$ および-45配向していることがわかる．また，配向角の大きさが一定であることから，図 1 に示す 向きの応力 $\sigma$ の大さとリタデーション $\delta$ 大きさが比例するとみなしてよい. 
一方，振幅が大きい場合に板近傍にDOLPの大きな值が残存する領域のAOPを計測すると，図 12 （f）に示すよ うに停止直後の板近傍では $A O P=45^{\circ}$ であることから，式（24）より，ミセルの軸は $90^{\circ}$ の方向を向いることがわ かる．異なる位相の時刻においても同様の結果を得た．このことから，板近傍には，このとき板に対して平行な 方向にミセルの強い配向を持った領域が常に存在していることがわかった．また，平衡点が上昇する領域におい ては，振動時にせん断波による振幅が小さいときと異なりAOPが $0^{\circ}$ と $90^{\circ}$ に達していない.

板近傍にDOLPの大きな值が残存する領域の発生は，板表面上で見積もったひずみ $\gamma_{0}$ で整理することができる が，スタートアップ流れでの SIS（Shear Induced Structure）の発生に必要とされるひずみ量（大内他，2007）と比 較し，非常に小さな值となっている．また，本実験の実験条件ではSIS の特徵である溶液の白濁や透過光輝度の 減少などが観察されず，PIV 計測において板近傍と他の領域で減衰比の変化なども見られなかった．よって，本 研究の結果が配向の変化のみによるものか, SIS 発生によるものかを判断するには, SIS を観測する他の手法を必 要とする.

\section{5. 結 言}

ひも状ミセル水溶液中を伝播するせん断波に対し, 偏光撮像素子をもつカメラによるリタデーション分布の計 測ならびにPIVによる速度波形の計測を行うことで，せん断波の可視化計測と動的粘弾性測定を行った．以下に 本研究より得られた知見を示寸。

(1) 本手法によって比較的高い周波数領域におけるせん断波の伝播速度および減衰波形を計測することができた. せん断波の周期性を利用したサンプリングを用いることで，せん断波の周波数よりも低いフレームレートの カメラでも計測が可能である.

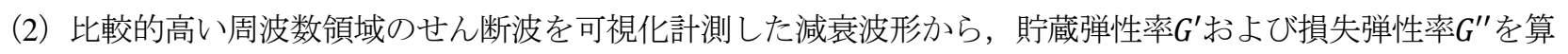
出し，本手法の有効性が示された.

（3）せん断波の偏光観察において，振動板の振幅と波長の比が一定值を超えると，リタデーション波形の平衡点 の上昇が起こり，波形の解析が不可能になる.これは，板に平行な方向にミセルの強い配向を持った領域が 板近傍に生じることに起因する.

\section{謝 辞}

本研究の試料溶液のレオメータによる測定は, 株式会社アントンパール・ジャパンの協力を得て行いました. ここに記して謝意を表します.

\section{文献}

Ferry, J. D., Viscoelastic properties of polymers, John Wiley \& Sons (1980), pp. 121-125.

Galante, S. R. and Frattini, P. L., The influence of end effects on birefringence measurements in nominally two - dimensional channel flows, Journal of Rheology (1978-present), 35, 1551-1581 (1991).

Gladden, J. R., Skelton, C. E. and Mobly, J., Shear waves in viscoelastic wormlike micellar fluids, J. The Journal of the Acoustical Society of America Express Letters 128 (2010), pp. EL268-EL273.

Gladden, J. R., Skelton, C. E. and Mobly, J., Shear waves in viscoelastic wormlike micellar fluids over a broad concentration range, The Journal of the Acoustical Society of America Express Letters Vol. 131 No. 3 (2012), pp. 2063-2067.

Gyr, A. and Bewersdorff, H. W., Drag reduction of turbulent flows by additives, Kluwer Academic Publishers (1995), pp. 157-174.

Kadoma, I. A., Ylitalo, C. and van Egmond, J. W., Structural transitions in wormlike micelles, Rheol Acta 36 (1997), pp. $1-12$.

大内真由美, 高橋勉, 白堅正高, $\mathrm{CTAB} / \mathrm{NaSal}$ 水溶液において形成されるせん断誘起構造のレオロジー特性 スター トアップ流れにおける粘度と弾性力の変化 , 日本レオロジ一学会誌 Vol. 35 No. 3 (2007), pp. 107-114.

Shikata, T., Dahman, S. J. and Pearson, D. S., Rheo-optical behavior of wormlike micelles, Langmuir, 10(1994), pp. 3470-3476.

四方俊幸, 丹羽宏和, 森島洋太郎, メカニカルインピーダンスを用いた粘弾性測定装置の試作, 日本レオロジー学 
会誌 Vol. 25 No. 1 (1997), pp. 19-23.

\section{References}

Ferry, J. D., Viscoelastic properties of polymers, John Wiley \& Sons (1980), pp. 121-125.

Galante, S. R. and Frattini, P. L., The influence of end effects on birefringence measurements in nominally two - dimensional channel flows, Journal of Rheology (1978-present), 35, 1551-1581 (1991).

Gladden, J. R., Skelton, C. E. and Mobly, J., Shear waves in viscoelastic wormlike micellar fluids, The Journal of the Acoustical Society of America Express Letters 128 (2010), pp. EL268-EL273.

Gladden, J. R., Skelton, C. E. and Mobly, J., Shear waves in viscoelastic wormlike micellar fluids over a broad concentration range, The Journal of the Acoustical Society of America Express Letters Vol. 131 No. 3 (2012), pp. 2063-2067.

Gyr, A. and Bewersdorff, H. W., Drag reduction of turbulent flows by additives, Kluwer Academic Publishers (1995), pp. 157-174.

Kadoma, I. A., Ylitalo, C. and van Egmond, J. W., Structural transitions in wormlike micelles, Rheol Acta 36 (1997), pp. $1-12$.

Ouchi, M., Takahasi, T., and Shirakashi, M., Rheological properties of shear-induced structure in CTAB/NaSal Aqueous Solution $\sim$ viscosity and elasticity change under start-up flows , NIHON REOROJIGAKKAISHI Vol. 35 No. 3 (2007), pp. 107-114 (in Japanese).

Shikata, T., Dahman, S. J., and Pearson, D. S., Rheo-optical behavior of wormlike micelles, Langmuir, 10 (1994), pp. 3470-3476.

Shikata, T., Niwa, H. and Morisima, Y. A new system for viscoelastic measurement with mechanical impedance, NIHON REOROJIGAKKAISHI Vol. 25 No. 1 (1997), pp. 19-23 (in Japanese). 